\title{
Pulmonary Findings Of H1N1 Infection In Children With Malign Disease
}

\section{H1N1 Infeksiyonu Geçiren Kanserli Hastalarda Akciğer Bulguları}

\author{
Aysenur Bahadır', Erol Erduran², Osman Bahadır ${ }^{3}$ \\ Karadeniz Technical University, School of Medicine, Department of Pediatric Hematology \\ Karadeniz Technical University, School of Medicine, Department of Pediatrics \\ Karadeniz Technical University, School of Medicine, Department of Otorhinolaryngology
}

Dergiye Ulaşma Tarihi: 08.04.2016 Dergiye Kabul Tarihi: 08.02.2017 Doi: 10.5505/aot.2017.38257

\begin{abstract}
ÖZET
Giriș: H1N1 influenza virusu, malign hastalıklarda ve kronik hastalıklarda immunsupresyona bağlı öldürücü olabilmektedir. Hastalar gribal enfeksiyon semptomları, yüksek ateş, ishal şikayeti ile daha çok başvurmakta, klinik tablo solunum yetmezliğine kadar gidebilmektedir. Bu çalışmada kanser tanısı ile izlenen H1N1 enfeksiyonu geçiren hastaların radyolojik bulgularının değerlendirilmesi amaçlandı.

Materyal Method: Ocak 2010- Ocak 2016 y1lları arasında hematoloji-onkoloji kliniğinde kanser tanısı ile takip edilen 94 vakadan, H1N1 PCR'ı pozitif olan 10 vaka çalışmaya dahil edildi. Vakalar absolü nötrofill sayısına gore; $\geq 500 / \mu \mathrm{L}$ üstü absolü nötrofil sayısı olanlar Grup A (beş vaka) ve $<500 \mu \mathrm{L}$ altı absolü nötrofil sayısı olanlar grup B (beş vaka) olmak üzere ikiye ayrıldı. Hastaların akciğer grafileri ve toraks bilgisayarlı tomografi sonuçları değerlendirildi.

Sonuçlar: On hastadan sekizi aktif kemoterapi alıyordu. Başlangıçta tüm hastaların akciğer grafisi normaldi. Grup A'da bir, grup B'de beş hasta olmak üzere altı hastanın (\%60) akciğer grafi bulgularında bilateral pulmoner infiltrasyon izlendi. En sık akciğer alt zonlarında tutulma mevcuttu ve en belirgin akciğer grafi bulgusu yama şeklinde konsalidasyondu. Grup A'da iki, grup B'de beş hastada olmak üzere on hastadan yedisinde (\%70) toraks bilgisayarlı tomografide buzlu cam alanları ve konsalidasyon gözlendi. Grup A'da bir vaka, grup B'de ciddi nötropenisi olan üç vaka olmak üzere toplam dört vaka (\%40) solunum yetmezliğinden kaybedildi.

Tartışma: H1N1 influenza virus enfeksiyonu geçiren hastalarda hastanın klinik bulgusu olmasına rağmen erken dönemde akciğer grafi bulguları sıklıkla normal olabilmektedir. Klinik tablo ilerledikçe radyolojik bulgu belirginleşmektedir. Bu nedenle yüksek doz kemoterapi tedavisi alan ya da tedaviye dirençli malign hastalarda gribal enfeksiyon semptomları saptandığında akla H1N1 influenza virus enfeksiyonu gelmeli ve tedaviye hemen başlanmalıdır. Erken tedaviye başlanması bu hastalarda hayat kurtarıcı olabilmektedir.
\end{abstract}

Anahtar Kelimeler: H1N1 influenza enfeksiyonu, radyolojik bulgular, malign hastalık

\begin{abstract}
Introduction: H1N1 influenza virus may be fatal due to immunosuppression in malignant diseases and chronic diseases. Patients frequently present with influenza-like symptoms, high fever, and diarrhea, and the clinical course may be aggressive, possibly ending in respiratory failure. The purpose of this study was to examine the radiological findings of patients who were diagnosed with cancer and had H1N1 infection.

Material and Method: Ten cases with a positive H1N1 PCR among 94 patients who were followed-up with a diagnosis of cancer at the hematology and oncology clinic between January 2010 and January 2016 were included in the study. Cases were divided into two groups according to the absolute neutrophil count, having a neutrophil count $\geq 500 / \mu \mathrm{L}$ in Group A (five patients) and neutrophil count $<500 \mu \mathrm{L}$ in Group B (five patients). Chest X-ray and thoracic computed tomography of the patients were evaluated.

Results: Eight of ten patients received active chemotherapy. Chest x-rays of all patients were initially within normal ranges. Bilateral pulmonary infiltration was observed in the findings of chest $\mathrm{X}$-ray in six patients $(60 \%)$, one in Group A and five in Group B. The most frequently involvement was at the lower zones of the lungs. The most obvious chest $x$-ray finding was a patch-shaped consolidation. Seven out of ten patients (70\%), two in group A and five in group B, had a ground glass appearance and consolidation in thoracic computed tomography. A total of four cases $(40 \%)$ died due to respiratory failure, one in group A and three with severe neutropenia in group B. Discussion: Early chest X-ray findings might frequently be normal in patients who have H1N1 influenza virus infection at the moment, although they have clinical signs. Radiological findings become more significant with the advancement of the clinical picture. Therefore, H1N1 influenza virus infection should be considered when
\end{abstract}


symptoms of influenza infection are encountered in patients who are receiving high dose chemotherapy or who have a malignant disease resistant to therapy, and treatment should be started immediately. The immediate initiation of treatment may be lifesaving in this group of patients.

Keywords: H1N1 influenza infection, radiologic findings, malign disease

\section{Introduction}

The first case of the $2009 \mathrm{H} 1 \mathrm{~N} 1$ virus surfaced in Mexico in April. Subsequently, the virus spread quickly through many countries. The World Health Organization escalated the pandemic to alert phase 6 in early June 2009 (1). The pandemic $\mathrm{H} 1 \mathrm{~N} 1$ virus caused severe illness and death in previously healthy young and middle aged persons (2). The signs and symptoms of the H1N1 virus are fever, cough, sore throat, body aches, headache, chills, fatigue, nausea, vomiting and/or diarrhea $(3,4)$.

H1N1 influenza can cause lethal diseases in patients undergoing high dose chemotherapy, having resistance or uncontrolled malign disease and primary or secondary immune deficiency, pregnant women, and elderly individuals. People at high risk should receive an antiviral agent (oseltamivir) as soon as the flu symptoms appear $(4,5)$.

The most common cause of death in H1N1 influenza is respiratory failure. The radiologic findings of patients with H1N1 virus infection are multifocal patchy peripheral, rounded, peribronchial and ground glass opacities (GGO), and pleural effusions $(5,6,7)$.

The purpose of this report is to discuss the radiological findings of pandemic H1N1 virus in children with malign diseases.

\section{Material and Method}

Ten cases with a positive H1N1 PCR among 94 patients who were followed-up with a diagnosis of cancer at the hematology and oncology clinic between January 2010 and January 2016 were included in the study.

The 10 patients were divided into two groups. Group A consisted of five patients whose absolute neutrophil count of $\geq 500 / \mu \mathrm{L}$. Group B consisted of the remaining five patients in which absolute neutrophil count of $<500 / \mu \mathrm{L}$ in initial laboratory testing. The initial chest radiographs on admission were obtained in all patients. The follow-up chest radiographs and subsequent computed tomography (CT) examinations were performed within 2-5 days in which clinical course got worsen and respiratory distress developed. The abnormalities were characterized as consolidation (opacification obscuring the underlying vessels), ground-glass opacity (GGO; increased attenuation without obscuring the underlying vessels), nodules.

Neutropenic fever was firstly considered in these malign patients. Therefore, these patients were initially treated with broadspectrum systemic antibiotic (ceftazidime 100$150 \mathrm{mg} / \mathrm{kg} / \mathrm{day}$, amikacin $15 \mathrm{mg} / \mathrm{kg} /$ day) and granulocyte colony stimulating factor (G-CSF $5-10 \mu \mathrm{g} / \mathrm{kg} /$ day). Amphotericin B was added in patients whose fever was persistent despite antibiotics and abnormal radiological findings occurred. Oseltamivir (according to weight of children $<15 \mathrm{~kg} 2 \times 30 \mathrm{mg}, 15-23 \mathrm{~kg} 2 \times 45 \mathrm{mg}$, 23$40 \mathrm{~kg} 2 \times 60 \mathrm{mg},>40 \mathrm{~kg} 2 \times 75 \mathrm{mg}$ ) was also started because of presence of resistant fever, frequent cough, watery and mucusless diarrhea, and coinciding pandemic H1N1.

The nasopharyngeal swab for H1N1 influenza was performed because of flulike symptoms and coinciding pandemic H1N1. H1N1 was confirmed with real-time reverse transcription polymerase chain reaction.

\section{Results}

The study population numbered 10 malign patients. The clinical characteristics of the patients are shown in Table1. The presenting symptoms in all patients were fever greater than $38^{\circ} \mathrm{C}$, cough, diarrhea, and nasal discharge. Physical examinations revealed nasal and postnasal serous to purulent discharge, hyperemic mucosa on nasal cavity and oropharyngeal wall. Chest auscultations in all patients did not reveal any findings on admission. 
Table 1: Clinical characteristics of 10 patients infected with H1N1

\begin{tabular}{|c|c|c|c|c|c|c|c|c|c|c|}
\hline & \multicolumn{5}{|c|}{ GROUP A } & \multicolumn{5}{|c|}{ GROUP B } \\
\hline & Patient 1 & Patient 2 & Patient 3 & Patient 4 & Patient 5 & Patient 6 & Patient 7 & Patient 8 & Patient 9 & Patient 10 \\
\hline $\begin{array}{l}\text { Histopathologic } \\
\text { diagnosis }\end{array}$ & ALL & ALL & NBL & NHL & MDS & ALL & ALL & ALL & AML & ALL \\
\hline Age (year) & 4 & 5 & 4.5 & 17 & 17 & 14 & 3.5 & 8 & 15 & 15 \\
\hline Sex & male & male & male & female & female & female & female & male & female & female \\
\hline $\mathrm{WBC}(/ \mu \mathrm{L})$ & 2700 & 1200 & 2900 & 27200 & 7200 & 3600 & 1400 & 300 & 200 & 600 \\
\hline $\mathrm{ANC}(/ \mu \mathrm{L})$ & 1200 & 600 & 1000 & 19400 & 1900 & 480 & 170 & 0 & 0 & 0 \\
\hline Chest radiograph & Normal & Normal & Normal & $\begin{array}{l}\text { minimal noduler } \\
\text { infiltration and } \\
\text { patch opacities }\end{array}$ & $\begin{array}{l}\text { Bilateral } \\
\text { pulmonary } \\
\text { consolidation }\end{array}$ & $\begin{array}{l}\text { Bilateral } \\
\text { pulmonary } \\
\text { consolidation }\end{array}$ & $\begin{array}{l}\text { Bilateral } \\
\text { pulmonary } \\
\text { consolidation }\end{array}$ & $\begin{array}{l}\text { Bilateral } \\
\text { pulmonary } \\
\text { consolidation }\end{array}$ & $\begin{array}{l}\text { Bilateral } \\
\text { pulmonary } \\
\text { consolidation }\end{array}$ & $\begin{array}{l}\text { Bilateral } \\
\text { pulmonary } \\
\text { consolidation }\end{array}$ \\
\hline $\begin{array}{l}\text { Computerized } \\
\text { Tomography }\end{array}$ & No & No & No & GGO & GGO & No & No & GGO & GGO & GGO \\
\hline $\begin{array}{l}\text { Mechanical } \\
\text { ventilation }\end{array}$ & No & No & No & No & Yes & No & No & Yes & Yes & Yes \\
\hline Outcome & $\begin{array}{l}\text { Recovere } \\
\text { d }\end{array}$ & Recovered & $\begin{array}{l}\text { Recovere } \\
\text { d }\end{array}$ & Recovered & Died & Recovered & Recovered & Died & Died & Died \\
\hline
\end{tabular}

ALL: Acute lymphoblastic leukemia, AML: Acute myeloid leukemiaNBL: Neuroblastoma, NHL: Non-Hodgkin lymphoma, MDS: Myelodisplastik syndrome WBC: White blood countANC: Absolute neutrophil countGGO: Ground Glass Opacities 
Of these malign patients in Grup A there were two patients with acute lymphoblastic leukemia (ALL), one patient with neuroblastoma (NBL), one patient with non-hodgkin lymphoma (NHL), one patients with myelodisplastik syndrome (MDS). Of these patients, 3 patients were undergoing chemotherapy. Their ages ranged from 4 years to 17 years. Three were males and two were females. The initial chest radiographic images were normal. In Grup A, the follow-up chest radiographic images of two patients within 2-5 days were abnormal. But, it was developed minimal nodular infiltrate and patch opacities in patients with NHL and bilateral involvement on chest radiographic image in patient with MDS within 2 to 5 days. At the following of these two patients, respiratory distress developed and the findigs on chest radiographic increased and concurrent CT evaluation showed GGO. Subsequent CT evaluation of two patients in group A showed GGO and focal consolidation most commonly found in the central and lower lung zones on the right and upper and lower lung zones on the left. All patients were confirmed to have H1N1. Three patients in group A were treated with multiple broad-spectrum antibiotics and with oseltamivir. Antifungal therapy was also added according to CT findings in two patients in group A. Antifungal therapy was ended when H1N1 was confirmed. In group A, four patients completely cured Patient 5 with rhabdomyosarcoma received chemotherapy 5 years ago. This patient was also being followed with diagnosis of MDS for nearly a year and receiving support of a red blood cell and platelet transfusions about every 10 days. On the 15 th day of admission acute respiratory distress syndrome (ARDS) developed in patient with MDS. The patient then mechanically ventilated and later died at the follow-up.

In Grup B there were 4 patients with ALL and 1 patient with Acute myeloid leukemia (AML). All patients received active chemoteraphy. Two patients were resistant to treatment. One patient was high risk ALL. One of the patients was male, the others were female and their ages varied between $3.5-15$ years. ANS numbers were between 0-480. Patients initially had normal chest radiographic findings, but within 2-5 days bilateral pulmonary infiltration was observed on chest x-ray of all patients. At the follow-up of three patients (Patient 8, Patient 9, Patient 10), subsequent CT evaluation showed GGO after development of raspiratory disttress and progression of chest $\mathrm{x}$ ray findings. Subsequent CT evaluation of three patients in group B showed GGO and focal consolidation most commonly found in the central and lower lung zones on the right and upper and lower lung zones on the left. The extent of disease was greater in group B patients. Both chest radiography and CT showed extensive bilateral lung disease involving four or more lung zones in all patients. The lung abnormalities were initially most commonly found in the lower lung zones. The predominant chest radiographic finding was patch consolidation. The CT examinations showed predominantly a combination of GGO and consolidation (Figure 1,2).

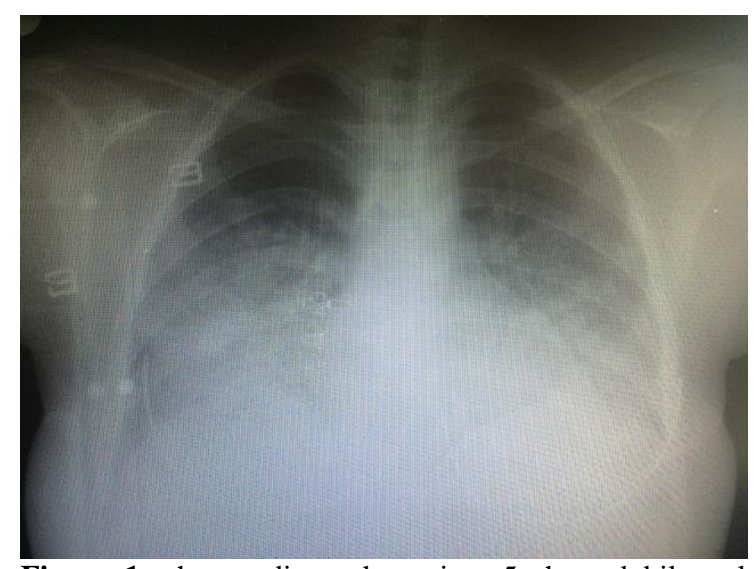

Figure 1, chest radiograph, patient 5 showed bilateral nodular infiltration, patch opacities a.

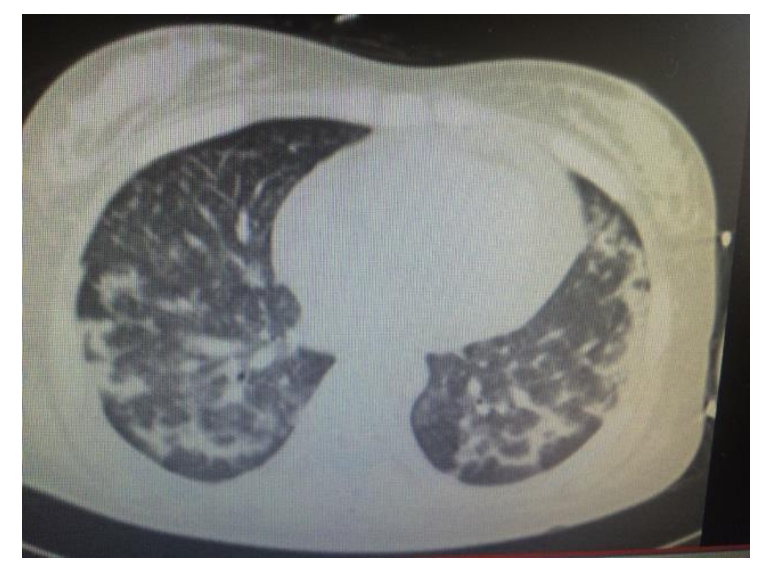

Figure 2: chest computerized tomography, patient 5 showed bilateral pulmonary ground glass opacities and focal consolidation

All patients were confirmed to have H1N1. Two patients group B were treated with multiple broad-spectrum antibiotics and with oseltamivir. Antifungal therapy was ended when H1N1 was confirmed. 
Patient 8 with resistant ALL was hospitalized with complaints of fever and cough on the second day after ending his chemotherapy. Patient 9 with relapse AML was hospitalized with complaints of fever, cough and diarrhea after an aggressive multiagent chemotherapy. Patient 10 with high risk ALL was hospitalized with complaints of fever, cough and diarrhea for three days while she was treated with aggressive multiagent chemotherapy. ARDS developed within 5-15 days in three patients (patient 8,9,10) in group A despite multiple broad-spectrum antibiotics, oseltamivir, and antifungal therapy. These patients required mechanical ventilation. The disease was severe and all patients died.

Statistical analysis could not be performed because the number of cases was not sufficient between two groups. But, mortality rate was higher in Group B, which is neutropenic.

\section{Discussion}

Pandemic (H1N1) 2009 in the general pediatric population can have a wide range of presentation. One case series described the clinical spectrum of 43 children with pandemic (H1N1) 2009. The most common symptoms at presentation was fever $(\mathrm{n}=41,95 \%)$ and following cough ( $n=40,93 \%)$ (8). In our study, the common clinical symptoms were fever, dry cough, fatigue and diarrhea.

The H1N1 virus commonly affects young to middle-aged patients, more than half the patients were 13-47 years and 90\% of patients were $<52$ years of age. Otherwise, seasonal influenza commonly affects elderly and young children (2). The patients who are at a higher risk, such as pregnant women, children from six months to 19 years of age, chronic medical or immunosuppressive conditions (e.g. undergoing chemotherapy) suffer severe illness caused by this virus (4). Six pregnant women died due to pneumonia and subsequent acute respiratory distress syndrome requiring mechanical ventilation (9). Our patients, aged from 3.5 to 17 years, who had malign diseases undergoing high dose chemotherapy and resistance leukemia, died due to ARDS.

Agarvall et al (10) tried to evaluate the imaging appearances both of the mild and the severe forms of the illness. Their findings indicated that the initial chest radiographic images were normal in more than half of patients with H1N1 infection, most of whom were out-patients. They determined that the predominant chest radiographic findings were GGO alone or with patch consolidation, which is the second most common predominant radiologic finding. They also observed that the most frequent pattern of radiologic abnormality was bilateral alveolar disease with lower and central lung preponderance. In hospitalized patients, the abnormalities progressed to severe air-space disease (10). Similarly, the predominant chest radiographic finding was patch consolidation. Consolidation and GGO were the most common findings on the chest CT examination in all cases of severe neutropenic patients.

Perez-Padilla et al (2) described 18 fatal cases of H1N1 as having abnormal chest radiography and 11 patients as having bilateral patch air-space disease affecting the basal segments and involving three to four lung segments (2).

Mollura et al (5) reported that a fatal case of H1N1 displayed a pattern of rounded peripheral GGO on the chest CT. They also emphasized that the imaging findings of their case suggest a differential diagnosis of atypical infections (viral infections, Mycoplasma, Chlamydia, or Legionella infections), septic emboli, ARDS, cryptogenic organizing pneumonia, eozinophylic pneumonitis and hypersensitivity pneumonitis. Moreover, they observed that the CT findings of the patient was different from hydrostatic or cardiogenic pulmonary odema, which usually shows a perihilar distribution of confluent GGO associated with pleural effusion $(11,12)$.

Increasing recognition of the halo sign and air-crescent sign by improved CT technology has greatly facilitated the diagnosis of invasive pulmonary aspergillosis in immunocompromised patients. Although these radiological features are characteristic, they are not diagnostic of invasive pulmonary aspergillosis $(13,14,15)$.

We did not initially suspect H1N1 infection in patients with severe neutropenia since the clinical findings related to H1N1 were not so distinct. Three of our patients received intensive chemotherapy and later developed neutropenic fever. Therefore, we started the treatment of severe neutropenicsepsis and continued it. Furthermore, the lung and CT findings were reported as aspergillosis. These 
patients were started on oseltamivir ampiric due to the presence of $\mathrm{H} 1 \mathrm{~N} 1$ pandemic influenza. However, we lost our patients despite the treatment since they underwent intensive chemotherapy and had severe neutropenia. Hence, we consider that H1N1 treatment should be started immediately by paying more attention to pandemic periods, taking into account that clinical manifestations of $\mathrm{H} 1 \mathrm{~N} 1$ can be confused with other illnesses, particularly aspergillosis.

Conclusion, H1N1 influenza should be considered in patients undergoing high dose chemotherapy and having resistance malign disease with complaints of cough, fever, diarrhea, and flu-like symptoms. We suggest that the mortality rate is high in patients with malign diseases with severe neutropenic in initial hemogram, and in patients undergoing intensive chemotherapy and having resistance malign disease. However, we observed in this study that H1N1 influenza infection in patients with cancer may not have initially obvious radiographic findings. In addition, it was observed that the most predominant radiological findings were patch consolidation on chest radiographic and consolidation and GGO on the lower zone of thorax CT when clinical signs progressed.

\section{Conflict of interest statement: None}

\section{References}

1. World Health Organisation. New influenza A (H1N1) virus: global epidemiological situation June 2009. Wkly Epidemiol Rec. 2009;84:249-260

2. Perez-Padilla R, de la Rosa- Zamboni D, Ponce de Leon S, et al. Pneumonia and respiratory failure from swine-origin influenza A (H1N1) in Mexico. N Engl J Med 2009;361:680-689

3. Kuzdan C, Soysal A. H1N1 Infection in Children. Turkiye Klinikleri J Pediatr Sci 2010;6(4):68-77

4. Cerit G N, Özkiraz S, Asri S, Çetinkaya R. Risk Factors of Severe Outcomes Among Patients
Admitted to Hospital with Pandemic (H1N1) Influenza. Turkiye Klinikleri J Anest Reanim 2011;9(3):196-201

5. Mollura DJ, Asnis DS, Crupi RS, et al. Imaging findings in a fatal case of pandemic swine-origin influenza A (H1N1). AJR2009;193:1500-1503

6. Abu Bakar N, Ehsan N. Chest Radiograph Findings In Novel Swine-Origin Influenza A (H1N1) Virus (SOIV) Infection: A UKMMC Experience. Med J Malaysia Vol 70 No 2 April 2015

7. Iovine NM, Morris JG, Fredenburg K, et al. Severity of Influenza $\mathrm{A}(\mathrm{H} 1 \mathrm{~N} 1)$ Illness and Emergence of D225G Variant, 2013-14 Influenza Season, Florida, USA. Emerging Infectious Diseases. Vol. 21, No. 4, April 2015 DOI: http://dx.doi.org/10.3201/eid2104.141375.

8. Larcombe PJ, Moloney SE, Schmidt PA. Pandemic (H1N1) 2009: A clinical spectrum in the general paediatric population. Arch Dis Child (10.1136/adc.2009.176859) November 10, 2009

9. Jamieson DJ, Honein MA, Rasmussen SA, et al. H1N1 2009 influenza virus infection during pregnancy in the USA. Lancet 2009;374:451-458

10. Agarwall PP, Cinti S, Kazerooni EA. Chest radiographic and CT findings in Novel Swine-Origin influenza $\mathrm{A}(\mathrm{H} 1 \mathrm{~N} 1)$ virus infection. $\mathrm{AJR}$ 2009; 193:1488-1493

11. John SD, Ramanathan J, Swischuk LE. Spectrum of clinical and radiographic findings in pediatric mycoplasma pneumania. RadioGraphics 2001;21:121-131

12. Webb RW, Higgins CB, Remy J, et al. Thoracic imaging: pulmonary and cardiovascular radiology, 1st ed. Philadelphia: PA Lippincott Williams, 2005

13. Caillot D, Couaillier JF, Bernard A, et al. Increasing volume and changing characteristics of invasive pulmonary aspergillosis on sequential thoracic computed tomography scans in patients with neutropenia. J Clin Oncol 2001;19: 253-259

14. Caillot D, Mannone L, Cuisenier B, Couaillier JF. Role of early diagnosis and aggressive surgery in the management of invasive pulmonery aspergillosis in neutropenic patients. Clin Microbiol Infect 2001;7:54-61

15. Grene RE, Schlamm HT, Oestmann JW, et al. Imaging findigs in acute invasive pulmonery aspergillosis: clinical significance of the halo sign. Clin Infect Dis 2007;44:373-379 